Counsellia: Jurnal Bimbingan dan Konseling 8 (1), 7 - 18 | Mei 2018

Copyright $@ 2017$ Universitas PGRI Madiun

ISSN: 2088-3072 (Print) / 2477-5886 (Online)

Available online at: http://e-journal.unipma.ac.id/index.php/JBK

DOI: 10.25273/counsellia.v8i1.2268

\title{
Aspect, Validity, And Reliability Family Support Perception Scale for Substance Abuse Disorders
}

\author{
Agus Supriyanto $^{1)}$, Nurlita Hendiani ${ }^{2)}$ \\ Fakultas Keguruan dan Ilmu Pendidikan, Universitas Ahmad Dahlan, Yogyakarta ${ }^{1)}$ \\ agus.supriyanto@bk.uad.ac.id ${ }^{1)}$ \\ Balai Besar Rehabilitasi, Badan Narkotika Nasional, Bogor ${ }^{2)}$ \\ nurlitahen@gmail.com ${ }^{2)}$
}

\begin{abstract}
Abstrak
Presepsi orang dengan Gangguan Penyalahgunaan Zat (GPZ) yang sedang menjalani program rehabilitasi tentang dukungan keluarga memiliki peran kuat proses pemulihan dan pencegahan kekambuhan. Pengukuran presepsi dukungan keluarga berguna untuk pengembangan konseling keluarga. Tujuan penelitian untuk menemukan aspek presepsi dan bentuk dukungan keluarga dari orang dengan GPZ untuk pulih dari adiksi narkoba dan butir-butir pernyataan pada instrumen skala presepsi dukungan keluarga. Penelitian menggunakan pendekatan mixed methods dengan transformatif sekuensial. Intrument penelitian berupa studi dokumentasi berupa analisis teks, wawancara, dan survei pada individu GPZ/ N=217. Analisis penelitian dengan analisis deskriptif kualitatif tentang kajian jurnal dan buku, focus group dicussion untuk penentuan butir-butir pernyataan, dan analisis deskriptif kuantitatif dari hasil uji beda untuk mengetahui validitas dan reliabilitas instrumen. Temuan mengungkap konsep dan operasionalisasi presepsi dukungan keluarga melalui dua aspek presepsi, yaitu kognisi dan afektif. Bentuk dukungan keluarga meliputi (1) dukungan emosional, (2) dukungan penghargaan, (3) dukungan informasi, dan (4) dukungan konkret. Skala presepsi dukungan keluarga memiliki 46 butir pernyataan valid dengan koefisien nilai Corrected Item-Total Correlation $\geq 0.148$. Koefisien reliabilitas skala presepsi dukungan keluarga adalah 0,861 dengan kategori reliabilitas tinggi. Skala presepsi dukungan keluarga dapat digunakan untuk mengidentifikasi tingkat presepsi dukungan keluarga pada orang dengan GPZ dari adiksi narkoba.
\end{abstract}

Kata Kunci: presepsi, dukungan keluarga, rehabilitasi narkoba

\begin{abstract}
People perception of Substance Abuse Disorders (GPZ) who are undergoing rehabilitation program on family support has a strong role recovery and relapse prevention. Measuring perception of family support is useful for family counseling development. The goal of research to find aspects of perception and a form family support from people with GPZ to recover from drug addiction on family support perception scale instruments. The research uses mixed methods approach with sequential transformative. Research instrument form documentation study in the form of text analysis, interview, and survey on individual GPZ/ $N=217$. The research analysis with qualitative descriptive analysis of journal and book study, focus group discussion to the determination of statement points, and quantitative descriptive analysis from
\end{abstract}


different test result to know validity and reliability of the instrument. The findings reveal the concept and operationalization of family support perception through two perception aspects, ie cognition, and affection. Forms of family support include (1) emotional support, (2) award support, (3) information support, and (4) concrete support. The family support perception scale has 46 valid statements with the value coefficient of Corrected Item-Total Correlation $\geq 0.148$. The reliability coefficient of the family supported perception scale is 0.861 with the high-reliability category. The family support perception scale can be used to identify the level of family support on people with GPZ from drug addiction.

Keywords: perception, family support, drugs rehabilitation

\section{INTRODUCTION}

Drugs or narcotics, psychotropic substances, and addictive substances dangerous to the human body. Drug trafficking cases through online and organized transactional markets are dominated by a small number of immigrant groups that cause violence, health in the form of dependence, psychotic disorders, and mental disorders (Fazey, 2007; Paoli\& Reuter, 2008; Snyder, 2009; Degenhardt\& Hall, 2012; Dolliver, 2015; Broséus, Rhumorbarbe, Mireault, Ouellette, Crispino, \& Décary-Hétu, 2016). Prescription drug abuse negatively potentially reinforcing negative behavior and social norms (Hanson, Cannon, Burton, \& Giraud-Carrier, 2013). The impact of the social environment on drug abuse comes from the influence of the wider community (Kendler, Maes, Sundquist, Ohlsson, \& Sundquist, 2014) and economic factors shape the risk behavior and health of drug users (Galea \& Vlahow, 2002).

Quality of relationship of parents and adolescents can represent groups of high-risk substance abuse (Hummel, Shelton, Heron, Moore, \&
Bree, 2013). As a result of the problems families have an impact on family members in abusing substances. The use of medicinal addictive substances contributes to an increase in abuse, resulting in many health consequences (Sairam, \& Manchikanti, 2014). Lack of assistance designed for family members affected by Substance Abuse Disorder (GPZ) causing stress, pain, and suffering to family members (Orford, Velleman, Natera, Templeton, \& Copello, 2013).

Other facts show that relapse in people with GPZ who are undergoing the rehabilitation program. Relapse is a fall back to the initial behavioral pattern (Reber\& Reber, 2010). Individuals with drug addiction who try to stop drug use in an addiction treatment center can help determine risk factors for drug use (Hosseini, Moghimbeigi, Roshanaei, \& Momeniarbat, 2014). The approach used in rehabilitation or addiction treatment and overcoming risk factors is family adherence. Multidimensional family therapy (MDFT) can reduce the prevalence of dependence (Sexton\& Lebow, 2016; Rigter, Henderson, 
Pelc, Tossmann, Phan, Hendriks... \& Rowe, 2013).

Drug rehabilitation is a recovery effort undertaken by counselors to assist people with GPZ to recover from addiction. Myrick (2011), rehabilitation counselors offer a wide range of services to people with physical, emotional, and/or developmental disabilities. Rehabilitation or relapse prevention is a recovery phase-oriented to the needs of people who have or had a dependence detoxification therapy and formally require access to previous recovery phase (United Nations Office on Drugs and Crime, 2014). A balanced approach to ensuring that people suffering from chronic pain can get the relief they need while minimizing the potential negative consequences (Volkow, 2014).

Services provided by counselors to help the psychic recovery, emotions, and potential developments of clients. Systemic interventions include family therapy and family approaches based on the problematic of drug abuse (Carr, 2014). The family is the primary means of healing in the rehabilitation process. Family support has an important role to play in the healing process. Support from family raises the confidence to recover from drug addiction, or called by the family as the locus of control in the development of self-efficacy (Manaffe, 2010). The posttraumatic growth of drug addicts related to emotion-focused coping, positive reappraisal, acceptance, and denial (Hendiani \& Supriyanto, 2016).

Expectations of a drug rehabilitation program are selfefficacy to recover from drug addiction. Perception of family support on GPZ undergoing drug rehabilitation program be decisive to recover from drug addiction and relapse prevention. The role of the family can develop the perception of family support substance users. Perception is the process that individuals use to manage and interpret their sensory impressions in giving meaning to the environment (Robbins, 2007). The user's perception of the family can be a source of social support for other family members in solving health problems, which is categorized into three aspects: cognition, emotion, and conation (Walgito, 2010). The types of social support available within the family are concrete support, emotional support, emotional support, advice support, and, award support (Dolan, Canavan, \& Pinkerton, 2006).

Development of cognitive function in neurocognitive rehabilitation programs was implemented as part of an addiction treatment (Rezapour, DeVito, Sofuoglu, \& Ekhtiari, 2016). Use of assessment appropriate, relevant, valid, and reliable will greatly support the implementation process 
of guidance and counseling approaches for people with GPZ undergoing drug rehabilitation programs (Supriyanto, 2017).

Perception of family support in the GPZ who are undergoing rehabilitation needs to be measured to determine the level of family support perceptions and soon realized by counselors, drug rehabilitation program organizers, and family people with GPZ. Instruments that can be developed in the form of perception of family support scale. Perception of family support scale is used as an assessment to determine the level of perception of family support people with GPZ who are undergoing drug rehabilitation programs and can be implemented as a measuring tool. Research findings described the process of preparing perception of family support scale as an instrument is valid, reliable, and known aspects of family support perceptions that fit the concepts and applications. The use of instruments also takes into account the goal of an instrument, one of which measures change (Lord, Corsello, \& Grzadzinski, 2014).

\section{RESEARCH METHOD}

This research uses mixed methods approach. Research design using the design of sequential transformative. Results research have the goal of finding valid and reliable statement points on the family- supported perception scale instrument.

The research instrument was developed through documentation study in the form of text analysis, interview, and survey. Research design in mixed methods approaches through six stages. First, the stage of literature studies in journals and scientific books. Second, the preparation of a grain interview statement through forum group discussion (FGD). Third, interviews about the grains statement to experts judgment and research subjects. Fourth, the development of statement items according to aspects. Fifth, survey the results of the statement item development according to aspects. Finally, test the validity and reliability.

The first stage, finding the aspect of family support preception through literature studies (journals and scientific books) containing aspects of perception and forms of family support to recover from drug addiction. The second stage, the forum group discussion (FGD) with experts. FGD results found indicators of family support perceptions and the preparation of statement points. In the third stage, the statements are validated by two experts and two practitioners (addiction counselors) to find out the validity of the content of the statement items on aspects of perception and form of family support. 
The fourth stage, development of 48 items of family support perception. The fifth stage, a survey to test item statement family support perception on 217 people with GPZ undergoing rehabilitation program at Central Rehabilitation, National Narcotics Departement in Indonesia. The sixth stage, survey results are analyzed to know the validity and reliability of the instrument through product moment correlation formula to determine the level of validity and Alpha Cronbach formula to determine the level of reliability. The findings will show the data about the scale of family support perception as well as valid and reliable items to be able to measure the perception of family support of drug users undergoing drug rehabilitation programs.

The research analyzes used qualitative descriptive analysis of journal and book study as documentation study, focus group discussion determination item statement, and the validation results of experts and practitioners (addiction counselors) about the content of the statement items. The analysis in this study also used quantitative descriptive analysis from different test results to find out the validity and reliability of family support perception instruments. The results of the analysis will find facts about the dimensions, indicators, and grains statement from the perception of family support to recover from drug addiction with the subject is a person with GPZ who are undergoing drug rehabilitation program.

\section{RESULT AND DISCUSSION}

The findings from the literature study through the analysis of journal and scientific books become the main reference to know aspects of perception and form of family support. Perception is the process of seeking information obtained through sensing to be understood based on awareness or cognition (Sarwono, 2002). Perception is also a cognitive process that allows individuals to interpret and understand the environment (Kreitner \& Kinicki, 2005). Family support is known as a work style and a series of activities that generate positive reinforcement of informal social networks through an integrated program (Canavan, et.al., 2006). It was concluded that the perception of family support was an assessment of his interaction with the family who had a role to motivate in achieving healing.

Individual perceptions appear in three aspects, namely cognition, affection, and conation (Walgito, 2010). Perception can also be divided into two aspects, namely cognition and affection (Coren, Ward, \& Enns, 1999). Family support has four concepts, namely emotional support, esteem support, informational support, and tangible support (Cutrona et.al., 2000). Type 
of social support available in the family is a concrete support, emotional support, support advice, support award (Dolan, Canavan, \& Pinkerton, 2006). Findings from the literature study concluded that the aspects of family support perception in this study are (1) cognition and (2) affection, as well as forms of family support consisting of (1) emotional support, (2) awards support, (3) information support, and (4) concrete support. Aspects of perception and form of family support as a guide for the preparation of the grid of the family perception scale appliance scale and statement items.

Table 1. Grid of Family Support Perception Scale

\begin{tabular}{|c|c|c|c|}
\hline & $\begin{array}{l}\text { Aspects of } \\
\text { Perception }\end{array}$ & $\begin{array}{l}\text { Forms of } \\
\text { Family } \\
\text { Support }\end{array}$ & Indicator \\
\hline \multirow[t]{4}{*}{1.} & \multirow[t]{4}{*}{ Cognition } & $\begin{array}{l}\text { Tangible } \\
\text { Support }\end{array}$ & $\begin{array}{l}\text { Assessment: } \\
\text { support } \\
\text { providing for } \\
\text { troubleshooting. }\end{array}$ \\
\hline & & $\begin{array}{l}\text { Emotional } \\
\text { Support }\end{array}$ & $\begin{array}{l}\text { Assessment: } \\
\text { family attitudes } \\
\text { of empathy, } \\
\text { attention, \& } \\
\text { caring. }\end{array}$ \\
\hline & & $\begin{array}{l}\text { Information } \\
\text { Support }\end{array}$ & $\begin{array}{l}\text { Assessment: } \\
\text { support in the } \\
\text { form of advice } \\
\text { and family } \\
\text { opinion to } \\
\text { provide comfort } \\
\text { \& certainty. }\end{array}$ \\
\hline & & $\begin{array}{l}\text { Esteem } \\
\text { Support }\end{array}$ & $\begin{array}{l}\text { Assessment: } \\
\text { encouragement } \\
\text { and family } \\
\text { expression of } \\
\text { beliefs to be } \\
\text { able to solve } \\
\text { problems. }\end{array}$ \\
\hline \multirow[t]{2}{*}{2} & \multirow[t]{2}{*}{ Affection } & $\begin{array}{l}\text { Tangible } \\
\text { Support }\end{array}$ & $\begin{array}{l}\text { Individual } \\
\text { feelings: } \\
\text { support } \\
\text { provides a need } \\
\text { for } \\
\text { troubleshooting. }\end{array}$ \\
\hline & & Emotional & Feelings: the \\
\hline
\end{tabular}

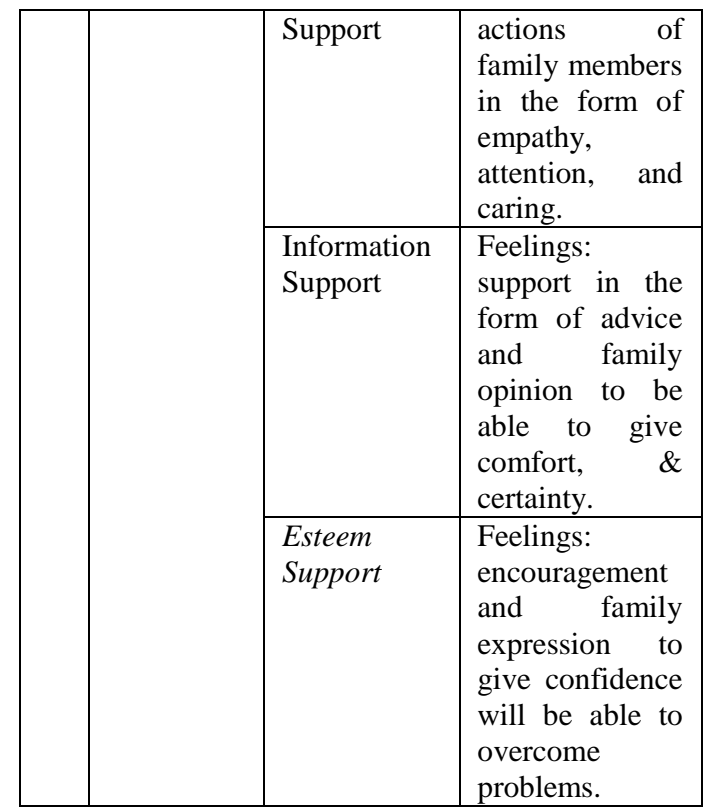

The findings point statement obtained from a focus group discussion (FGD) with experts and addiction counselors. Focus group method and indepth individual in order to obtain indepth knowledge concerning attitudes, perceptions, beliefs, and opinions of individuals regarding a specific health issue (Then, Rankin, \& Ali, 2014; Carter, Bryant-Lukosius, DiCenso, Blythe, \& Neville, 2014). The problems in this study are the grain of statement from aspects of perception and form of family support. Content validation results from practitioners and experts found indicators of family support perception and 48 point statements. Indicators of family support perception are (1) cognition aspect includes assessment of support providing problem solving, family attitudes of empathy, attention, \& care, support of family advice and opinions, as well as encouragement and family expression of beliefs to be able to solve problems, (2) the affective aspects, including feeling the support presents the need to 
overcome the problem, family attitudes of empathy, attention, \& care, support advice and opinions from family, and encouragement and family expression of beliefs to be able to solve problems. The statement points match the psychological development of people with GPZ who are undergoing drug rehabilitation programs.

The statement items on the family support perception scale that have been compiled are tested with $\mathrm{N}=217$ respondents (people with GPZ who follow drug rehabilitation programs). Test the validity and reliability of family support perception scale assisted with SPSS 19 applications. The result of product moment correlation analysis can be concluded that from 48 total item statement amount, 46 items declared valid, so 46 items are retained and 2 items are declared void, with coefficient value Corrected Item-Total Correlation $\geq 0.148$ on each item statement. Alpha Cronbach analysis results, the instrument reliability coefficient of the scale of perception of family support is 0.861 which is included in the category of high reliability. The findings form the basis for family support perception scale instruments eligible to be used to determine the level of scale perception of family support to recover from drug addiction. Validity and reliability to provide valid instruments and empirical data (Csikszentmihalyi \& Larson, 2014).

Table 2. Statement of Cognitive Aspects

\begin{tabular}{|l|c|}
\hline \multicolumn{1}{|c|}{$\begin{array}{c}\text { Cognitive Aspects } \\
\text { (+/-) }\end{array}$} & $\begin{array}{c}\text { Corrected } \\
\text { Item-Total } \\
\text { Correlation }\end{array}$ \\
\hline $\begin{array}{l}\text { Families understand } \\
\text { addiction that I have } \\
\text { experienced about drugs }\end{array}$ &, 186 \\
\hline $\begin{array}{l}\text { The family asked my } \\
\text { condition while undergoing } \\
\text { rehabilitation program }\end{array}$ &, 250 \\
\hline For me, my family cares &, 179 \\
\hline
\end{tabular}

\begin{tabular}{|c|c|}
\hline $\begin{array}{l}\text { about my condition, when } \\
\text { I'm down }\end{array}$ & \\
\hline $\begin{array}{l}\text { The family tried to } \\
\text { encourage me when I was } \\
\text { saturated with rehabilitation. }\end{array}$ & 298 \\
\hline $\begin{array}{l}\text { Support from family helped } \\
\text { me in overcoming problems } \\
\text { during rehabilitation. }\end{array}$ & 290 \\
\hline $\begin{array}{l}\text { I think my family is happy to } \\
\text { hear my progress. }\end{array}$ & ,257 \\
\hline $\begin{array}{l}\text { When I am confused about } \\
\text { the completion of the } \\
\text { rehabilitation, the family } \\
\text { gave several options so as } \\
\text { not to relapse or recurrence. }\end{array}$ & 258 \\
\hline $\begin{array}{l}\text { My family gave many } \\
\text { directives in choosing } \\
\text { friends. }\end{array}$ & 231 \\
\hline $\begin{array}{l}\text { I'm sure the family will } \\
\text { facilitate my positive plan } \\
\text { after completion of } \\
\text { rehabilitation }\end{array}$ & ,226 \\
\hline $\begin{array}{l}\text { Families try to provide my } \\
\text { daily needs in rehabilitation }\end{array}$ & 294 \\
\hline $\begin{array}{l}\text { I think my family is trying to } \\
\text { help to take care of my needs } \\
\text { when I'm down }\end{array}$ & 205 \\
\hline $\begin{array}{l}\text { The family encouraged me } \\
\text { that going through } \\
\text { rehabilitation was a good } \\
\text { step than in prison. }\end{array}$ & ,307 \\
\hline $\begin{array}{l}\text { My family emphasizes drugs } \\
\text { spoil life. }\end{array}$ & 223 \\
\hline $\begin{array}{l}\text { The family still doesn't know } \\
\text { about the drug world that I } \\
\text { experienced }\end{array}$ & ,277 \\
\hline $\begin{array}{l}\text { My family is indifferent to } \\
\text { my condition in } \\
\text { rehabilitation }\end{array}$ & 462 \\
\hline $\begin{array}{l}\text { For me, the family has no } \\
\text { meaning whatsoever }\end{array}$ & ,446 \\
\hline $\begin{array}{l}\text { Family indifferent to my } \\
\text { complaints when undergoing } \\
\text { rehabilitation }\end{array}$ & ,457 \\
\hline $\begin{array}{l}\text { I thought the family dumped } \\
\text { me at this rehabilitation }\end{array}$ & 487 \\
\hline $\begin{array}{l}\text { The family didn't have time } \\
\text { to talk to me via phone or } \\
\text { meet directly. }\end{array}$ & 531 \\
\hline Family forced me to follow & ,494 \\
\hline
\end{tabular}




\begin{tabular}{|l|c|}
\hline $\begin{array}{l}\text { their wishes about the plan } \\
\text { after the completion of } \\
\text { rehabilitation. }\end{array}$ &, 494 \\
\hline $\begin{array}{l}\text { In my opinion, the family } \\
\text { only adds a problem to my } \\
\text { recovery. }\end{array}$ &, 397 \\
\hline $\begin{array}{l}\text { I always tell my family about } \\
\text { my needs during } \\
\text { rehabilitation }\end{array}$ &, 410 \\
\hline $\begin{array}{l}\text { Families forced me to limit } \\
\text { spending during } \\
\text { rehabilitation. }\end{array}$ & \\
\hline
\end{tabular}

Table 3. Statement of Affective Aspect Statement

\begin{tabular}{|l|c|}
\hline \multicolumn{1}{|c|}{$\begin{array}{c}\text { Affective Aspects } \\
\text { (+/-) }\end{array}$} & $\begin{array}{c}\text { Corrected } \\
\text { Item-Total } \\
\text { Correlation }\end{array}$ \\
\hline $\begin{array}{l}\text { I feel calm after telling about } \\
\text { my condition in this } \\
\text { rehabilitation }\end{array}$ &, 238 \\
\hline $\begin{array}{l}\text { I feel comfortable when the } \\
\text { family asks me about my } \\
\text { health condition here. }\end{array}$ &, 364 \\
\hline $\begin{array}{l}\text { I'm glad the family has been } \\
\text { concerned with the problems } \\
\text { I faced }\end{array}$ &, 283 \\
\hline $\begin{array}{l}\text { I think the family reinforced } \\
\text { me that this disease can be } \\
\text { recovered. }\end{array}$ &, 340 \\
\hline $\begin{array}{l}\text { I love family praise for my } \\
\text { development during the } \\
\text { rehabilitation program }\end{array}$ &, 395 \\
\hline $\begin{array}{l}\text { I feel happy when the family } \\
\text { gives the option plan after } \\
\text { coming out of rehabilitation }\end{array}$ &, 310 \\
\hline $\begin{array}{l}\text { I think the family advised me } \\
\text { to be able to follow the } \\
\text { rehabilitation program well. }\end{array}$ &, 354 \\
\hline $\begin{array}{l}\text { I feel proud to have a family } \\
\text { that understands my needs } \\
\text { here. }\end{array}$ &, 319 \\
\hline $\begin{array}{l}\text { It's happy the family believes } \\
\text { I can manage my expenses in } \\
\text { rehabilitation. }\end{array}$ &, 352 \\
\hline $\begin{array}{l}\text { My family is indifferent to } \\
\text { what I do }\end{array}$ &, 466 \\
\hline $\begin{array}{l}\text { It's sad that the family doesn't } \\
\text { care about my recovery plan. }\end{array}$ &, 404 \\
\hline
\end{tabular}

\begin{tabular}{|l|c|}
\hline $\begin{array}{l}\text { The family doesn't provide } \\
\text { my needs here. }\end{array}$ &, 530 \\
\hline $\begin{array}{l}\text { The family let me down when } \\
\text { I was down }\end{array}$ &, 531 \\
\hline $\begin{array}{l}\text { I am disappointed the family } \\
\text { ignored my complaints in } \\
\text { undergoing this rehabilitation. }\end{array}$ &, 477 \\
\hline $\begin{array}{l}\text { It's sad that the family doesn't } \\
\text { care about my development in } \\
\text { the rehabilitation program }\end{array}$ &, 521 \\
\hline $\begin{array}{l}\text { I feel depressed because my } \\
\text { family threw me here }\end{array}$ &, 470 \\
\hline $\begin{array}{l}\text { Family scares me by telling } \\
\text { friends outside who still use } \\
\text { drugs. }\end{array}$ &, 522 \\
\hline $\begin{array}{l}\text { I was sad when the family } \\
\text { forced me to follow their } \\
\text { wishes. }\end{array}$ &, 437 \\
\hline $\begin{array}{l}\text { The family is afraid that I will } \\
\text { use drugs again. }\end{array}$ &, 192 \\
\hline $\begin{array}{l}\text { I am sad to the family to } \\
\text { silence me when I need } \\
\text { support from them. }\end{array}$ &, 481 \\
\hline $\begin{array}{l}\text { I feel depressed if family } \\
\text { scold me. }\end{array}$ &, 436 \\
\hline $\begin{array}{l}\text { Families always blame me for } \\
\text { drug problems. }\end{array}$ &, 295 \\
\hline $\begin{array}{l}\text { I was disappointed when no } \\
\text { news from family. }\end{array}$ &, 401 \\
\hline
\end{tabular}

Like the results of research Dingle, Stark, Cruwys, \& Best, (2015), the movement of a substance using identity to the identity of recovery is an important step in the treatment of substance abuse. Important research results from Bertrand, Richer, Brunelle, Beaudoin, Lemieux, \& Ménard, (2013), about the importance of the need to facilitate access to and involvement of parents in the treatment of substance abuse as a major power. Anggriana, Margawati, \& Wardani (2016) revealed that the higher the social support of the family the lower the dual role conflict, and the lower the social support of the family the higher the dual role conflict. 
Hopefully, the use of assessment appropriately, relevant, valid, and reliable will greatly support the implementation process of guidance and counseling approaches to recover from drug addiction (Supriyanto, 2017).

The family support perception scale can be used to measure the perceptions of people with GPZ about the form of family support to recover and undergoing rehabilitation programs. The level of family support perception of the family support perception scale forms the basis for developing action plans to prevent relapse and recover from drug addiction through a family approach. The plan will set out a rehabilitation program that guides addiction counselor in providing guidance and counseling to people with GPZ. Significant reductions in the risk of recurrence of heavy drug use and drinking through mindfulness-based relapse prevention (MBRP) with psychosocial and group-based care, and integrating the practice of cognitive relapse prevention approaches (Bowen, Witkiewitz, Clifasefi, Grow, Chawla, Hsu, ... \& Larimer, (2014).

The combination of the approach to be important in healing programs for the GPZ. The approach in guidance and counseling through peer support groups is the form most widely used treatment for individuals who are recovering from substance abuse and substance dependence (O'Sullivan, Blum, Watts, \& Bates, 2015). Brief counseling of individuals with substance dependence through a combination of counseling, referral to special treatment and pharmacotherapy (Shapiro, Coffa, \& McCance-Katz, 2013).
The scale of family support perception has been developed can be used addiction counselor or researcher to identify individual perceptions with GPZ to recover from drug addiction. Counselors can design a counseling strategy to develop self-efficacy and prevent relapse. Information is required to fulfill the obligation to help assess the program (Posavac, 2015).

\section{CONCLUSION}

This research finds aspects of family support perception, valid and reliable statement points on family support perception scale instruments. The research was conducted to find the concept and operationalization of family support perception scale through two aspects of perception, ie cognitive and affective aspects, as well as a form of family support, ie tangible support, emotional support, informational support, and esteem support. Indicators of family support perception are (1) cognition aspect includes assessment of support providing problem solving, family attitudes of empathy, attention, \& care, support of family advice and opinions, as well as encouragement and family expression of beliefs to be able to solve problems, (2) the affective aspects, including feeling the support presents the need to overcome the problem, family attitudes of empathy, attention, \& care, support advice and opinions from family, and encouragement and family expression of beliefs to be able to solve problems. The statement points match the psychological development of people with GPZ who are undergoing drug rehabilitation programs.

Family support perception scale has 46 valid statement items with the 
Corrected Item-Total Correlation $\geq 0.148$ coefficient. The reliability coefficient of the family-supported perception scale is 0.861 which is included in the highreliability category. The findings of the family support perception scale can be used by an addiction counselor or researcher to identify the level of perception of family support from individuals with GPZ to recover from drug addiction and design a counseling strategy to develop strategies to prevent relapse.

\section{REFERENCES}

Anggriana, T. M., Margawati, T. M., \& Wardani, S. Y. (2016). Konflik Peran Ganda Pada Dosen Perempuan Ditinjau Dari Dukungan Sosial Keluarga. Counsellia: Jurnal Bimbingan dan Konseling, 5(1).

Bertrand, K., Richer, I., Brunelle, N., Beaudoin, I., Lemieux, A., \& Ménard, J. M. (2013). Substance abuse treatment for adolescents: how are family factors related to substance use change?. Journal of Psychoactive Drugs, 45(1), 28-38.

Bowen, S., Witkiewitz, K., Clifasefi, S. L., Grow, J., Chawla, N., Hsu, S. H., ... \& Larimer, M. E. (2014). Relative efficacy of mindfulness-based relapse prevention, standard relapse prevention, and treatment as usual for substance use disorders: a randomized clinical trial. JAMA psychiatry, 71(5), 547-556.

Broséus, J., Rhumorbarbe, D., Mireault, C., Ouellette, V., Crispino, F., \& Décary-Hétu, D. (2016). Studying illicit drug trafficking on Darknet markets: structure and organisation from a
Canadian perspective. Forensic science international, 264, 7-14.

Carr, A. (2014). The evidence base for family therapy and systemic interventions for child-focused problems. Journal of Family Therapy, 36(2), 107-157.

Carter, N., Bryant-Lukosius, D., DiCenso, A., Blythe, J., \& Neville, A. J. (2014). The use of triangulation in qualitative research. In Oncology nursing forum (Vol. 41, No. 5).

Coren, S., Ward, L.M., \& Enns, J.T. (1999). Sensation and Perception. Fort Worth: Harcourt College Publishers.

Csikszentmihalyi, M., \& Larson, R. (2014). Validity and reliability of the experience-sampling method. In Flow and the foundations of positive psychology (pp. 35-54). Springer Netherlands.

Cutrona, C. (2000). Family Support: Direction From Diversity. London: Jessica Kingsley Publishers

Degenhardt, L., \& Hall, W. (2012). Extent of illicit drug use and dependence, and their contribution to the global burden of disease. The Lancet, 379(9810), 55-70.

Dingle, G. A., Stark, C., Cruwys, T., \& Best, D. (2015). Breaking good: Breaking ties with social groups may be good for recovery from substance misuse. British journal of social psychology, 54(2), 236254.

Dolan, P., Canavan, J \& Pinkerton, J. (2006). Family Support as Reflective Practice. London: Jessica Kingsley Publishers.

Dolliver, D. S. (2015). Evaluating drug trafficking on the Tor Network: Silk Road 2, the sequel. International Journal of Drug Policy, 26(11), 1113-1123. 
Fazey, C. (2007). International policy on illicit drug trafficking: The formal and informal mechanisms. Journal of Drug Issues, 37(4), 755-779.

Galea, S., \& Vlahov, D. (2002). Social determinants and the health of drug users: socioeconomic status, homelessness, and incarceration. Public health reports, 117(Suppl 1), S135.

Hanson, C. L., Cannon, B., Burton, S., \& Giraud-Carrier, C. (2013). An exploration of social circles and prescription drug abuse through Twitter. Journal of medical Internet research, 15(9).

Hendiani, N. \& Supriyanto, A. (2016). Posttraumatic Growth pada Pecandu Narkoba (Landasan Pengembangan Program Konseling Pecandu Narkoba pada Proses Rehabilitasi). Prosiding. Yogyakarta: Universitas Ahmad Dahlan.

Hosseini, S., Moghimbeigi, A., Roshanaei, G., \& Momeniarbat, F. (2014). Evaluation of drug abuse relapse event rate over time in frailty model. Osong public health and research perspectives, 5(2), 92-95.

Hummel, A., Shelton, K. H., Heron, J., Moore, L., \& Bree, M. (2013). A systematic review of the relationships between family functioning, pubertal timing and adolescent substance use. Addiction, 108(3), 487-496.

Kendler, K. S., Maes, H. H., Sundquist, K., Ohlsson, H., \& Sundquist, J. (2014). Genetic and family and community environmental effects on drug abuse in adolescence: a Swedish national twin and sibling study. American Journal of Psychiatry, 171(2), 209-217.

Kreitner, R \& Kinicki, A. (2005). Perilaku Organisasi. Jakarta: Salemba Empat.
Lord, C., Corsello, C., \& Grzadzinski, R. (2014). Diagnostic instruments in autistic spectrum disorders. Handbook of Autism and Pervasive Developmental Disorders, Fourth Edition.

Manaffe, Y. (2010). Advokasi Pencegahan Penyalahgunaan Narkoba. Jakarta: Direktorat Advokasi Deputi Bidang Pencegahan BNN

Myrick, R. D. (2011). Developmental Guidance and Counseling : A Practical Approach Fifth edition. Minneapolis: Educational Media Corporation.

O’Sullivan, D., Blum, J. B., Watts, J., \& Bates, J. K. (2015). SMART Recovery: Continuing care considerings for rehabilitation counselors. Rehabilitation Counseling Bulletin, 58(4), 203 216.

Orford, J., Velleman, R., Natera, G., Templeton, L., \& Copello, A. (2013). Addiction in the family is a major but neglected contributor to the global burden of adult ill-health. Social Science \& Medicine, 78, 70-77.

Paoli, L., \& Reuter, P. (2008). Drug trafficking and ethnic minorities in Western Europe. European Journal of Criminology, 5(1), 13-37.

Posavac, E. (2015). Program evaluation: Methods and case studies. New York: Routledge.

Reber, A.S., \& Reber, E.S. (2010). Kamus Psikologi. Yogyakarta: Pustaka Pelajar.

Rezapour, T., DeVito, E. E., Sofuoglu, M., \& Ekhtiari, H. (2016). Perspectives on neurocognitive rehabilitation as an adjunct treatment for addictive disorders: From cognitive improvement to relapse prevention. Progress in brain research, 224, 345-369. 
Robbins, S. (2007). Perilaku Organisasi. Jakarta: Indeks.

Rigter, H., Henderson, C. E., Pelc, I., Tossmann, P., Phan, O., Hendriks, V., ... \& Rowe, C. L. (2013). Multidimensional family therapy lowers the rate of cannabis dependence in adolescents: A randomised controlled trial in Western European outpatient settings. Drug and alcohol dependence, 130(1), 85-93.

Sairam, A. G. S., \& Manchikanti, L. (2014). Assessment of the trends in medical use and misuse of opioid analgesics from 2004 to 2011. Pain physician, 17, E119E128.

Sarwono, S.W. (2002). Psikologi Sosial: Individu dan Teori-Teori Psikologi Sosial. Jakarta: Balai Pustaka.

Sexton, T.L., \& Lebow, J. (2016). Handbook of family therapy. Newyork: Routledge.

Shapiro, B., Coffa, D., \& McCanceKatz, E. F. (2013). A primary care approach to substance misuse. American family physician, 88(2), 113-121.

Snyder, R., \& Duran-Martinez, A. (2009). Does illegality breed violence? Drug trafficking and state-sponsored protection rackets. Crime, law and social change, 52(3), 253-273.

Supriyanto, A. (2017). Rehabilitation Counseling: Concept Assessment Guidance and Counseling For Drugs Abuse. In Prosiding Seminar Bimbingan dan Konseling (Vol. 1, No. 1, pp. 1930).

Shapiro, B., Coffa, D., \& McCanceKatz, E. F. (2013). A primary care approach to substance misuse. American family physician, 88(2), 113-121.

Then, K. L., Rankin, J. A., \& Ali, E. (2014). Focus group research: what is it and how can it be used?. Canadian Journal of Cardiovascular Nursing, 24(1).

United Nations Office on Drugs and Crime. (2003). Drug Abuse Treatment and Rehabilitation: a Practical Planning and Implementation Guide. Vienna

Volkow, N. D. (2014). America's addiction to opioids: heroin and prescription drug abuse. Senate Caucus on International Narcotics Control, 14.

Walgito, B. (2010). Pengantar Psikologi Umum. Yogjakarta: Andi Offset. 